\title{
PERIPHERAL PLASMA PROGESTERONE LEVELS DURING PREGNANCY IN THE PURE BREED ANATOLIAN SHEPHERD DOGS
}

Ayhan Baştan

\author{
Selim Aslan ${ }^{2}$
}

Muzaffer Çelebi ${ }^{3}$

\author{
Gebe Safkan Anadolu Çoban Köpeklerinde Plazma Progesteron Düzeyleri
}

Özet: Bu çalışmanın amacı gebe safkan Anadalu Çoban Köpeklerinde progesteron düzeylerini ortaya koymaktı.

Araştırmada yaşları 3-6 ve kilolart 45-55 kg arasında değişen 4 adet yetişkin köpek materyal olarak kullanildı. Vulvada ödem vaginada serosanguinöz kanlı akıntı görülenler köpekler izlenmeye başlandı. Bu köpeklere 2 günde bir "vaginal smear" yaptlarak uygun çiftleşme zamant belirlendi. "Vaginal smear"de \%80 ve daha yukart kornifiye epitel hücresi saptananlar çiftleştirildi. Çiftleşme günü gebeliğin 1. günü kabul edildi. Vulvada ödem ve vaginada akıntı saptanan köpeklere çiftleşme gününe kadar 2 ve çiftleşmeden sonra ise 7 günde bir ve doğum zamanı kan örnekleri alınd ve serumlar çıkartılarak, $-20{ }^{\circ} \mathrm{C}^{\prime}$ de saklandı. Progesteron düzeyleri RIA yöntemiyle belirlendi.

Proöstrus'un ortalarında ortalama progesteron konsantrasyonu $0.83 \pm 0.4 \mathrm{ng} / \mathrm{ml}$ idi. Bu değer artmaya devam etti ve çiftleşme günü $4.2 \pm 0.6 \mathrm{ng} / \mathrm{ml}$ olarak bulundu. Ortalama progesteron düzeyi diöstrus'un 10-15. Günlerinde ise $17 \pm 1.2 \mathrm{ng} / \mathrm{ml}$ idi. Gebeliğin 45. gününe kadar bu düzeyde seyretti ve 45. Günden sonra aniden düşmeye başladı. Doğumdan 48 saat önce ortalama progesteron seviyesi $4 \pm 0.3 \mathrm{ng} / \mathrm{ml}$ ve doğum zamanı $0.69 \pm 0.2 \mathrm{ng} / \mathrm{ml}$ olarak belirlendi.

Anahtar Kelimeler: Köpekler, Progesteron, Gebelik.

Summary: In this study, sexually mature 3-6 years old) Anatolian Shepherd Dogs, weighing 45-55 kg were used as materials. The females were closely observed for signs of oestrus (swelling of the vulva blood discharge) The optimum mating day was assessed retrospectively by using the criteria of standing response to the dogs, maximum vulval swelling and the second peak of cornified epithelial cells in a vaginal smear. Copulation was observed on the first or second day of exposure. The day of observed copulation was taken as the first day of pregnancy.

Blood samples for progesterone assay were collected at 16 am into evacuated tubes from the vein at 2 day intervals until mating and 7 day intervals until term. The blood was centrifuged and the serum frozen at $-20^{\circ} \mathrm{C}$ until asseyed. Progesterone was determined by RIA method.

\footnotetext{
${ }^{1}$ Doç.Dr., A.Ü. Veteriner Fakültesi, Doğum ve Jinckoloji Anabilim Dalı, Ankara.

${ }^{2}$ Dr., A.Ü. Veteriner Fakültesi, Doğum ve Jinekoloji Anabilim Dalı, Ankara.

${ }^{3}$ Dr., T.A.E.K. Lalahan Hayvan Sağlığı Nükleer Araştırma Enstitüsü, Ankara.
} 
Mean plasma progesterone concentrations were $0.83 \pm 0.4 \mathrm{ng} / \mathrm{ml}$ in midproestrus, rising above $0.8 \mathrm{ng} / \mathrm{ml}$ prior to the onset of standing heat. Mean progesterone concentrations in standing heat were $4.2 \pm 1.7 \mathrm{ng} / \mathrm{ml}$. Then, it increased gradually and by day 10 to 15 days of diestrus mean progesterone concentration was $17 \mathrm{ng} / \mathrm{ml}$. And maintained this level up to about 45 days after mating.

In the bitches, the level decreased rapidly later then 45 days after mating. Maternal progesterone concentration was obtained above $4 \mathrm{ng} / \mathrm{ml} 48$ hours prior to the whelping.

Mean progesterone concentration was $0.69 \pm 0.20 \mathrm{ng} / \mathrm{ml}$ on the day of parturation.

Key Words: Dogs, Progesterone, Pregnancy.

\section{Introduction}

The bitch has a prolonged luteal phase with persistence of the corpora lutea for 70-80 days in the non-pregnant animals $(1,8)$. Progesterone concentrations in the peripheral circulation of pregnant bitches are similiar to those of non-pregnant individuals and for this reason, unlike other species cannot be used to diagnose pregnancy $(3,4,9)$. The ovaries, with their functioning corpora lutea are essential for pregnancy. The bitch in proestrus is under the influence of estrogen. Progesterone concentrations throughtout all but the last 12 to 48 hours of beginning of estrus are signified by progesterone concentrations that rise above the critical $0.5 \mathrm{ng} / \mathrm{ml}$ plateu, while estrogen concentrations are declining $(3,5,14)$. Plasma progesterone concentration are typically ( 0.5 $\mathrm{ng} / \mathrm{ml}$ in mid-proestrus, rising above $0.5 \mathrm{ng} / \mathrm{ml}$ prior to the onset of standing heat or before the $\mathrm{LH}$ peak and continuing to increase for the following 15 to 25 days. By the first day 10 to 15 of diestrus the progesterone concentrations is usually above $25 \mathrm{ng} / \mathrm{ml}$ and some bitches may reach levels of 50 or $60 \mathrm{ng} / \mathrm{ml}$ or higher. Some reseachers reported that $(4,6,10,14)$, the concentration of progesterone is very low in proestrus with $0.2 \mathrm{ng} / \mathrm{ml}$ at the beginning and $0.6 \mathrm{ng} / \mathrm{ml}$ towards the end, followed by a slow increase in estrus and average peak ranging from $22.9 \pm 2.7 \mathrm{ng} / \mathrm{ml}$ on day 25 to $47 \pm 3.1 \mathrm{ng} / \mathrm{ml}$ 20-25 days after the $\mathrm{LH}$ peak. Usually after progesterone concentrations peak, they remain at that plateau for 7 to 15 days before beginning to decline slowly throughout the remainder of pregnancy. Concannon et al. (3) obtained mean maximum values of $29 \mathrm{ng} / \mathrm{ml}$ for pregnant. Steinetz et al. (12) reported that. the mean of the predicted values for serum progesterone concentration was $31.9 \pm 12.3 \mathrm{ng} / \mathrm{ml}$ in the pregnant bitches as evaluated at 4 weeks after mating. However, there was a lot of individual variation with peak values obtained between eight and 29 days after the $\mathrm{LH}$ peak in pregnant bitches. There is some evidence that at the time of implantation or just after implantation, progesterone concentrations increase, due possible to the effect of placental gonadotrophin. From about 30 days of gestation there is a gradual decrease in progesterone so that by about day 60 values $5 \mathrm{ng} / \mathrm{ml}$ are obtained followed by a sudden decline just before parturation to zero just afterwards (3).

A progesterone concentration $2 \mathrm{ng} / \mathrm{ml}$ was documented 36 to 48 hours prior the whelping $(3,4,5)$.

Some researhes $(3,7)$ obtined that, whelping bitches consistly had progesterone concentrations below the $1.0 \mathrm{ng} / \mathrm{ml}$ level. In one study, Concannon et al. (4) reported that whelping bitches maternal progesterone concentrations fall below $2 \mathrm{ng} / \mathrm{ml}$.

Materials and MethodsFour sexually mature (3-6 years old) Anatolian Shepherd Dogs, weighing 45-55 kg were used as materials. The females were closely observed for signs of oestrus (swelling of the vulva and blood discharge) and placed actively interested males when they appeared ready to mate 8-12 
days later. The optimum mating day was assessed retrospectively by using the criteria of standing response to the dogs, maximum vulval swelling and the second peak of cornified epithelial cells in a vaginal smear. Copulation was observed on the first or second day of exposure. The day of observed copulation was taken as the first day of pregnancy.

Blood samples for progesterone assay were collected at 16 am into evacuated tubes from the vein at 2 day intervals until mating and 7 day intervals until term. The blood was centrifuged and the serum frozen at $-20{ }^{\circ} \mathrm{C}$ until asseyed. Progesterone was determined by RIA method.

\section{Results}

In our study, mean plasma progesterone concentrations were $0.830 .4 \mathrm{ng} / \mathrm{ml}$ in mid- proestrus, rising above $0.8 \mathrm{ng} / \mathrm{ml}$ prior to the onset of standing heat and continued to increase for the following 15 to 25 days. By the first day of diestrus progesterone concentrations were invariably, above $2.50 \mathrm{ng} / \mathrm{ml}$ (mean $4.2 \mathrm{ng} / \mathrm{ml}$ ). Then, it increased gradually and by day 10 to 15 days of diestrus mean progesterone concentration was $17 \mathrm{ng} / \mathrm{ml}$. And maintained this level up to about 45 days after mating.

In the bitches, the level decreased rapidly later then 45 days after mating. Maternal progesterone concentration was obtained above $4 \mathrm{ng} / \mathrm{ml} 48$ hours prior to the whelping.

Mean progesterone concentration was $0.69 \pm 0.20 \mathrm{ng} / \mathrm{ml}$ on the day of parturation.

Mean progesterone concentration (Figure I) are shown.

Figure I: Individual progesterone concentration

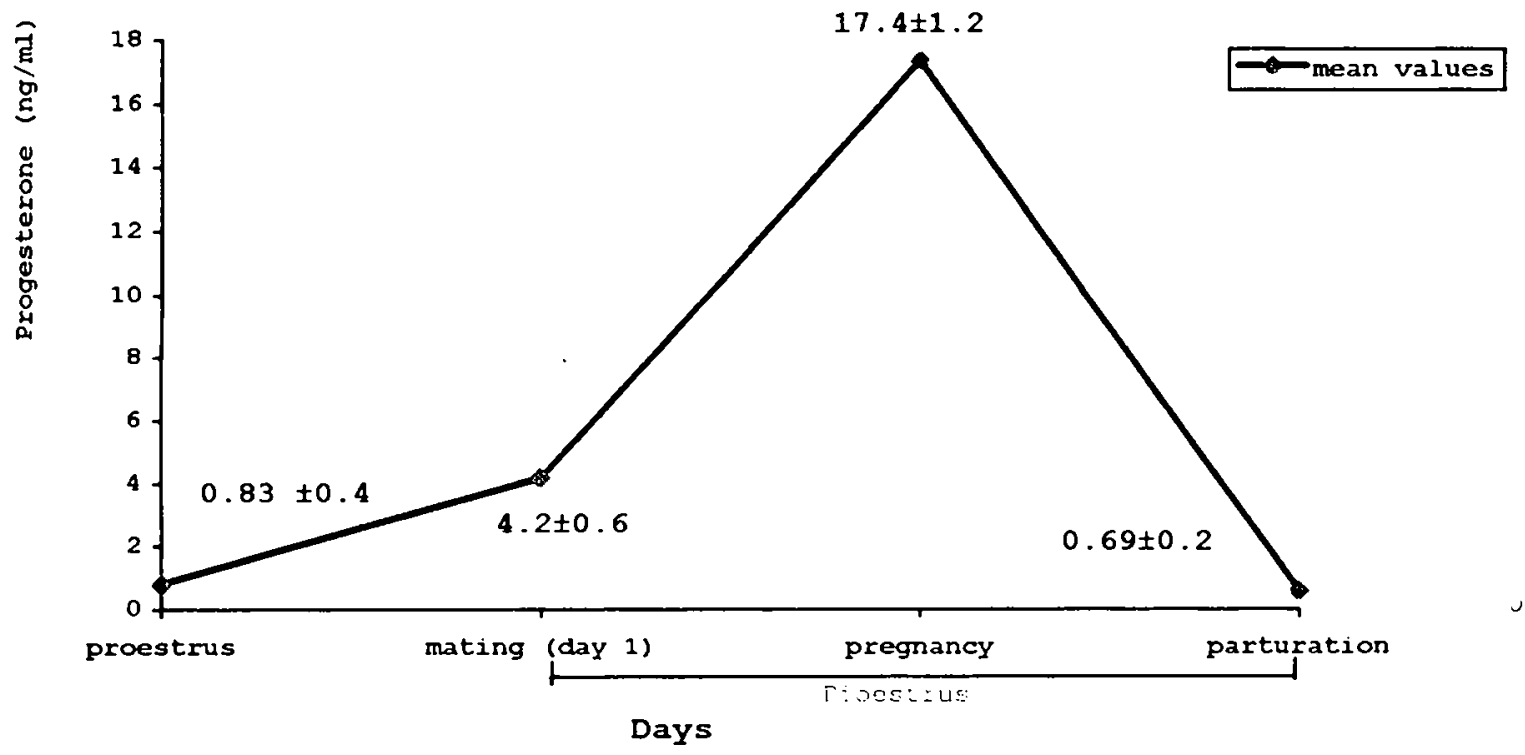

Figure I : Mean progesterone concentration

\section{Discussion}

Progesterone levels are typically $<0.5$ $\mathrm{ng} / \mathrm{ml}$ in mid-proestrus, rising above $0.5 \mathrm{ng} / \mathrm{ml}$ prior to the onset of standing heat or, before the LH peak and continuing to increase for the following 15 to 25 days $(3,4,5,10)$. By the first day of diestrus progesterone concentrations are invariable. Progesterone levels were noticed to increase remarkably 10 days or more after ovulation and reach a peak at the stage of implantation, or about 20 days after ovulation. As is clear from this results.

The magnitude of the preovulatory progesterone rise in the bitch is reported to be around $1 \mathrm{ng} / \mathrm{ml}$ at the beginning of the $\mathrm{LH}$ 
surge rising to $3 \mathrm{ng} / \mathrm{ml}$ during the surge and subsequently continuing to rise to around 5 to 7 $\mathrm{ng} / \mathrm{ml}$ at the time of ovulation $(5,6,11)$.

In the present study, the rate at which the mating levels of progesterone concentration increased $2.50-5.30 \mathrm{ng} / \mathrm{ml}$ was variable. The difference between these two rates of hormonal rise might reflect the pattern of the LH surge which caused by the interaction of oestradiol 17 $\beta$ from the follicles and $\mathrm{GnRH}$.

Bouchard et al (2) and Wright (15) predicted that, ovulation was estimated to occur when progesterone concentration was $4.9 \pm 1.0$ $\mathrm{ng} / \mathrm{ml}, 5.5 \mathrm{ng} / \mathrm{ml}$ with range of 3.4 to 6.6 $\mathrm{ng} / \mathrm{ml}, 4$ to $10 \mathrm{ng} / \mathrm{ml}$ respectively. Our findings are similiar to researchers.

Steinetz et al (13) reported that, the mean of the predicted values for serum progesterone concentration was $31.9 \pm 12.3 \mathrm{ng} / \mathrm{ml}$ in the pregnant bitches as evaluated at 4 weeks after mating. Our results are different from Steinetz et al (13), the difference might be due to breed variation.

From about 30 days of gestation there is a gradual decrease in progesterone so that by about day 60 values $5 \mathrm{ng} / \mathrm{ml}$ are obtained followed by a sudden decline just before parturation to zero just afterwards (4).

In this study, from about 45 days of gestation there was a gradual decrease in progesterone concentration so that by about day 60 values $5 \mathrm{ng} / \mathrm{ml}$ were obtained followed by a sudden decline just before parturation to zero afterwards. In this study, at day 45 of pregnancy, while the fall in the progesterone concentrations differs from the findings in the study of . Concannon et al $(3,4)$, the progesterone concentrations at the time of parturation are similiar. We think that, this difference might be related to the variations between breeds.

\section{REFERENCES}

1. Austad, R., Lunde, Astrid and Sjaastad, Q.V. (1976) Peripheral plasma levels of oestradiol- 17 ( and progesterone in the bitch during the oestrous cycle, in normal pregnancy and after dexamethasone treatment.; J Reprod Fert. 46, 129 136.

2. Bouchard, G.F., Solorzano, N., Concannon, P.W. Younquist and Bierschwal, C.J. (1991) Determination of ovulation time in bitches based on teasing. vaginal cytology. and Elisa for progesterone.; Theriogenology. 25 (3), 211 216.

3. Concannon, PW., Hansel, W., Visek, W. (1975) Pregnancy and parturation in the bitch. Biol Reprod 16., 517-526.

4. Concannon, PW., Powers ME., Holder, W. (1977) Pregnancy and parturation in the bitch. Biol Reprod 16., 427.431

5. England, G.C.W.. Anderton, D.J., (1992). Determination of progestogen concentrations in the vaginal fluid of bitches in oestrus.; Veterinary Record. 130, 143-144.

6. England, G.C.W., Allen. W.E and Porter, D.J. (1989). A comparison of radioimmunoassay with quantitative and qualitative enzyme-linked immunoassay for plasma progestagen detection in bitchcs: Veterinary Record 125 . 107-108.

7. Gwyneth, E.J., Boyns, A.R., Cameron, E.H.D., Bell, E.T. Christic. D.W. and Parkes, M.F. (1973). Plasma oestradiol, luteinizing hormone and progesterone during pregnancy in the Beagle Bitches. J Reprod Fert. 35. 187-189.

8. Hadley, J.C. (1973). Variations in peripheral blood concentrations of progesterone and total free oestrogens in the non-pregnant bitch.; Veterinary Record 77. 43-45.

9. Holst, P.A., Phemister, R.D. (1992). Temporal sequence of cvents in the estrous cycle of the bitch; Veterinary Record, $15,142-144$

10. Mestre, j., Wanke, $M$ and Sucheyre, S. (1990). Exfoliate vaginal cytology and plasma concentrations of progesterone, luteinising hormone and oestradiol-17 (during oestrus in the bitch. J Small Animal Practice, 31, 568-570.

11. Renton, J.P. (1992). Compparison of endocrine changes and ultrasound as means of identifying ovulation in the bitch. Research in Veterinary Science, 53, 74-79.

12. Steinetz., B.G., Goldsmith, L.T., Harvey, H.J and Lust, G (1989). Serum relaxin and progesterone concentrations in pregnant, pseudopregnant, and ovariectomized, progestintreated pregnant bitches; Detection of relaxin as a marker of pregnancy, Am J Vet Res, 50

13. Steinetz, B.G., Goldsmith, L.T., Hasan, S.H and Lust, G. (1990). Diumal variation of senum progesterone, but not relaxin, prolactin, or estradiol- 17 (in the pregnant Bitch. Endocrinology. 127: 1057-106.3.

14. Tsutsui, T. (1982). Peripheral plasma gestagen icvels during the estrous cycle and pregnancy in the bitch. Jpn J Anim Reprod., 31, 150-156.

15. Wright, P.J. (1990). Application of vaginal cytology and plasma progestcrone determinations to the management of reproduction in the bitch; J Small Animal Practice, 31, 335340 . 